\title{
Effect of concentrate supplementation level on production, health and efficiency in an organic dairy herd
}

\author{
Jakob Sehested $^{\mathrm{a}, *}$, Troels Kristensen ${ }^{\mathrm{b}}$, Karen Søegaard ${ }^{\mathrm{c}}$ \\ ${ }^{a}$ Department of Animal Nutrition and Physiology, Research Centre Foulum, Danish Institute of Agricultural Sciences, P.O. Box 50, \\ DK-8830 Tjele, Denmark \\ ${ }^{\mathrm{b}}$ Department of Agriculatural Systems, Research Centre Foulum, Danish Institute of Agricultural Sciences, P.O. Box 50, \\ DK-8830 Tjele, Denmark \\ ${ }^{\mathrm{c}}$ Department of Crop Physiology and Soil Science, Research Centre Foulum, Danish Institute of Agricultural Sciences, P.O. Box 50, \\ DK-8830 Tjele, Denmark
}

\begin{abstract}
The proportions of organic feed and roughage in the feed ration for organic dairy cows have to reach 100 and $60 \%$, respectively, in 2005. The aim of this study was to elucidate the long-term effects of reducing or omitting concentrate supplementation to high genetic merit dairy cows on a basal ad libitum diet of clover-grass (silage and grazing). Three concentrate levels, $\mathrm{N}, \mathrm{L}$ and $\mathrm{L}+(38,0$ and $19 \%$ of dry matter (DM) intake, respectively) were investigated in a herd of 60 cows during 3 years. The production in group $\mathrm{N}$ was $6723 \mathrm{~kg}$ energy corrected milk (ECM) per cow year, based on an intake of $6226 \mathrm{~kg} \mathrm{DM}$ of which $38 \%$ was concentrates. In group L the omission of concentrates reduced intake to $4770 \mathrm{~kg}$ DM, and milk production to $5090 \mathrm{~kg}$ ECM per cow year. Milk protein content was reduced and milk free fatty acid content was increased, and the first calving interval was significantly increased, as compared to group $\mathrm{N}$. The intake in group $\mathrm{L}+\mathrm{was}$ $5226 \mathrm{~kg}$ DM per cow year of which $19 \%$ was concentrates. Milk production in group L + was reduced by only $493 \mathrm{~kg}$ ECM per cow year as compared to group $\mathrm{N}$, primarily due to a significantly improved feed conversion ratio (12\%). There were no indications of health problems associated with the reduced feeding levels.
\end{abstract}

(C) 2002 Elsevier Science B.V. All rights reserved.

Keywords: Milk production; Feeding strategy; Energy level; Extensive dairy; Dairy cow; Summer feeding; Pasture; Reproduction; Feed conversion

\section{Introduction}

In Denmark organic milk is produced in large,

\footnotetext{
*Corresponding author. Tel.: +45-89-99-1384; fax: +45-8999-1378.

E-mail addresses: jakob.sehested@agrsci.dk (J. Sehested), http://www.agrsci.dk/hef/jas (J. Sehested).
}

high-productive dairy units specialising in milk production. The production level is high, average $7500 \mathrm{~kg}$ milk, compared to results from organic herds in other European countries (Krutzinna et al., 1996; Reksen et al., 1999), but around $500 \mathrm{~kg}$ milk lower than that of conventional herds in Denmark. Of the organic herds $6 \%$ have more than $9000 \mathrm{~kg}$ milk per cow and $13 \%$ less than 6000 . Replacement 
rate and time of culling is comparable with conventional results in Denmark, with a replacement of $40 \%$ and average 2.37 lactations per cow (Nielsen, 2001).

Feeding of organic cows is based on grazing of clover-grass for 5-6 months and indoors, during the winter period, on silage ad lib. Amount and type of supplement is given according to farm specific conditions such as milk quota, genetic potential of the herd, amount and type of home-grown concentrates and market condition for feedstuffs and milk. Balancing energy and nutrient content of the ration with animal requirements is done under these limitations. Therefore, feeding strategy often is a compromise between practical and well known biological, and physiological factors.

Danish organic milk production has been characterized by a good balance between crop production and feed supply, as use of $10-20 \%$ conventional feeds has been allowed. However, due to EU legislation, the proportion of organic feed in the total ration has to reach $100 \%$ in 2005 at the latest, and there is also a demand for $60 \%$ roughage in the total ration (EU, 1999). This puts pressure to the market for supplementary feeds, and gives basis for an increasing proportion of roughage in the feeding ration and thereby a decreasing feeding level.

The present organic dairy production strategy does not mean that the production in all respects meet the demand for high animal health and welfare. Precaution for animal health and welfare is, to a certain degree, in opposite to objectives of high productivity and low costs (Sundrum, 2001). Strategies towards a lower production and a higher reliance on homegrown concentrates and roughage might be a way to overcome the conflict (Padel, 2000). However, there are a limited number of long-term studies of the effects of feeding level on dairy cows (Broster et al., 1993). Berg and Ekern (1993) found a negative cumulative effect of reduced concentrates level on milk production from first to second lactation, with 1 $\mathrm{kg}$ milk per $\mathrm{kg}$ extra concentrates in first lactation and $1.3 \mathrm{~kg}$ in second lactation. It is known, that the roughage quality is of significance for the level of milk production obtained, and this can be expected to be of increasing importance as the level of supplementation is reduced (Kristensen and Skovborg, 1990). Furthermore, reducing the feed intake level in high genetic merit dairy cows could be expected to have negative effects on health and maybe reproduction if it causes an increasing mobilisation of body reserves and a more negative energy balance (Kronfeld, 1982; Butler and Smith, 1989). For support of organic farming it is a main challenge for nutritionists to show new ways whereby appropriate diets can be composed by variety of on-farm produced feedstuffs without adverse effects on productivity, animal health and welfare (Jakobsen and Hermansen, 2001).

The aim of this study was to elucidate the shortand long-term effects on milk production, herd health and production efficiency of reducing or omitting concentrate supplementation to high genetic merit cows on a basal diet of clover-grass. This information is critical for an evaluation of alternative strategies for organic milk production.

\section{Materials and methods}

\subsection{Experimental design}

The experiment was conducted through a 3-year period from January 1997 until December 1999 at the organic experimental farm Rugballegaard under the Danish Institute of Agricultural Sciences. The dairy herd of approximately 60 cows was divided in three treatment groups, the treatments being level of concentrate supplementation to a clover-grass based ad libitum roughage ration.

Group N: Normal supplementation (Normal feeding level), approximately 15 cows supplemented according to normal practice for an expected yield potential of $7500 \mathrm{~kg}$ energy corrected milk (ECM) per cow year.

Group L: No supplementation (Low feeding level), approximately 15 cows given no supplementary feed. Group $L+$ : Reduced supplementation (Low-plus feeding level), approximately 30 cows supplemented with reduced amounts of concentrates.

\subsection{Animals and housing}

The herd consisted continuously of approximately 60 cows. During the experimental period a total of 
145 animals were assigned to one of the three groups, and of these 139 calved. Calving and replacements were evenly distributed over the year.

Initially, the herd was a mixture of black and white Danish Holstein (SDM), Danish Red Dairy Breed (RDM) and cross-bred dairy cows. During the experimental period only black and white Danish Holstein sires were used. Allocation of heifers (and initially cows) to the three groups was done according to breed, sire and calving date, as replacement rate was the same within each group. The distribution on breeds of the 139 cows that calved within the experimental period was $14 \%$ cross-bred, $24 \%$ RDM and 62\% SDM. However, this distribution differed slightly between groups, and therefore breed was a determining parameter in all applied statistical models.

The stable was a cubicle house with Calan gates for individual feeding. Two daily milkings were performed in a herringbone milking parlour.

\subsection{Feeding}

The feeds used were basically produced on the farm, but minor amounts of concentrates, minerals and vitamin supplements were imported to the farm. The average composition and quality of the ad libitum and supplementary feeds are shown in Table 1. The basic feed for all groups was clover-grass as silage in the winter and by grazing in the summer. A minor proportion of whole crop silages (covering crop for clover-grass undersown) and fodder beets were used. The main supplements were rolled rye, oats grain and rapeseed cake, but also dried grass pellets, dried sugar beet feed, molasses and soybean meal were used in minor amounts. All cows were supplemented with minerals and vitamins according to Danish recommendations (Strudsholm et al., 1992).

The basic feeding principle in groups $\mathrm{N}$ and $\mathrm{L}+$ was flat rate feeding (Østergaard, 1979), meaning that roughage was given ad libitum to all lactating cows, whereas concentrates were given in fixed amounts for 24 weeks after calving, and later through the lactation in reduced amounts according to milk yield, parity and body condition score.

Groups $\mathrm{N}$ and $\mathrm{L}+$ were given approximately 8 and $3 \mathrm{~kg}$ concentrate supplementation, respectively, in the first 24 weeks of lactation. The supplements were allocated at two to six daily feedings and consisted of pelleted mixtures, which balanced the total ration primarily in protein (amino acids absorbed in the small intestine (AAT) and protein balance in the rumen (PBV)), and partly in fat (fatty acids) according to the experimental plan and to Danish recommendations (Strudsholm et al., 1992).

During the winter period (only stable feeding, approximately November until May) all cows were fed ad libitum with the same basal roughage mixture, which was allocated twice daily. The main component was clover-grass silage, minor components were barley whole crop silage, barley-pea silage and fodder beets according to their proportion in the crop rotation. The aim was that cows in the non-supplemented group $\mathrm{L}$ should be able to consume a minimum of $95 \mathrm{MJ}$ NE per day (equivalent to 12

Table 1

Composition and quality of basal ad libitum fed rations used during winter periods, of the herbage above grazing height during grazing periods, and of the supplements allocated during the grazing seasons and the winter periods (per kg dry matter); calculated as a weighted average of the used mixtures or batches of feeds and standard error of the mean

\begin{tabular}{|c|c|c|c|c|c|c|c|c|c|c|c|}
\hline Season & Feed & $\begin{array}{l}\mathrm{DE} \\
(\mathrm{MJ})\end{array}$ & $\begin{array}{l}\mathrm{NE} \\
(\mathrm{MJ})\end{array}$ & SFU & $\begin{array}{l}\text { Org. } \\
\text { matter }(\mathrm{g})\end{array}$ & $\begin{array}{l}\text { Crude } \\
\text { fibre (g) }\end{array}$ & $\begin{array}{l}\text { Crude } \\
\text { protein (g) }\end{array}$ & $\begin{array}{l}\text { Crude } \\
\text { fat }(\mathrm{g})\end{array}$ & $\begin{array}{l}\text { AAT } \\
(\mathrm{g})\end{array}$ & $\begin{array}{l}\text { PBV } \\
(\mathrm{g})\end{array}$ & $\mathrm{n}$ \\
\hline \multirow{3}{*}{ Winter } & Ad lib. ration & $12.1 \pm 0.3$ & $5.9 \pm 0.2$ & $0.75 \pm 0.02$ & $882 \pm 14$ & $246 \pm 16$ & $142 \pm 11$ & $26 \pm 3$ & $69 \pm 1$ & $16 \pm 10$ & 10 \\
\hline & $\mathrm{L}+$ supplement & $14.9 \pm 0.3$ & $8.5 \pm 0.3$ & $1.08 \pm 0.04$ & $951 \pm 8$ & $99 \pm 12$ & $176 \pm 17$ & $64 \pm 9$ & $105 \pm 3$ & $16 \pm 13$ & 11 \\
\hline & $\mathrm{N}$ supplement & $14.8 \pm 0.3$ & $8.6 \pm 0.3$ & $1.09 \pm 0.03$ & $955 \pm 4$ & $83 \pm 12$ & $158 \pm 16$ & $55 \pm 4$ & $100 \pm 5$ & $-2 \pm 13$ & 5 \\
\hline \multirow{3}{*}{ Summer } & grazed herbage & $14.2 \pm 0.7$ & $7.6 \pm 0.6$ & $0.96 \pm 0.08$ & $924 \pm 8$ & $200 \pm 28$ & $220 \pm 42$ & - & $88 \pm 4$ & $60 \pm 35$ & 8 \\
\hline & $\mathrm{L}+$ supplement & $14.8 \pm 0.3$ & $8.2 \pm 0.3$ & $1.04 \pm 0.04$ & $946 \pm 10$ & $113 \pm 17$ & $142 \pm 16$ & $50 \pm 10$ & $105 \pm 4$ & $-13 \pm 14$ & 10 \\
\hline & $\mathrm{N}$ supplement & $14.9 \pm 3.2$ & $8.4 \pm 0.3$ & $1.07 \pm 0.04$ & $946 \pm 5$ & $94 \pm 15$ & $155 \pm 3$ & $50 \pm 4$ & $105 \pm 5$ & $-15 \pm 10$ & 4 \\
\hline
\end{tabular}

$\mathrm{DE}$, digestible energy; NE, net energy; SFU, feed units; AAT, amino acids absorbed in the small intestine; PBV, protein balance in the rumen. 
Scandinavian Feed Units (SFU)) of the ad libitum feed. In a few cases, the ad libitum ration was improved by adding concentrates.

The grazing management was a continuously grazing system, where each paddock was regulated in size according to the proportion of rejected area, increasing from $7 \%$ in June to $25 \%$ in September. The groups grazed in separate paddocks. For each group there were two replicates of paddocks, which were grazed every second day. According to expected intake per cow the stocking rate was the highest for the $\mathrm{N}$-group, and proportionally decreased for groups $\mathrm{L}+$ and L. During periods with reduced herbage allowance all cows were supplemented with a restricted amount of silage at the barn.

The grazing sward was composed of perennial ryegrass (Lolium perenne) and white clover (Trifolium repens). The average content of white clover above grazing height was $36 \%$ on a dry matter basis. Sward height, herbage quality and herbage mass were measured seven times during two of the three seasons (see Tables 1 and 2). Herbage mass and quality were determined to grazing height, which was measured by a ruler in 20 recent bites. Sward height was determined by a plate raising meter in 30 points. The seven samples per paddock during the season were not independent, and therefore a mean value per season was used for the statistical evaluation.

Feed intake in the stable was calculated from the daily recordings of allocation and refusal of feed by group. Feed samples were collected every second week and pooled every second month by feed type (or batch) for analysis of chemical composition. Grass samples and stable feeds were analysed for dry matter and ash according to AOAC (1990), crude protein by the Kjeldahl technique (AOAC, 1990), crude fat by acid hydrolysis and ether extraction according to Stoldt (1952), crude fibre by the method of Tecator (1978), and in vitro digestibility by the methods of Tilley and Terry (1963) and Weisbjerg and Hvelplund (1992).

\subsection{Reproduction, health and body weight}

Observation of heat was performed during four to five daily inspections. Insemination was initiated at first clear heat later than 42 days after calving. Test for pregnancy was performed routinely by the herd veterinarian once a month. The aim was to dry off the cows at day 56 before expected calving, or earlier in case of low yield $(<10 \mathrm{~kg} /$ day at two consecutive tests). Reproduction was recorded by dates of artificial insemination, dates of positive test of pregnancy, and calving dates. Clinical disease was diagnosed and recorded by the herd veterinarian. Treatment and re-treatment on the same animal within 10 days was calculated as one case. All cows were weighed fourth-nightly, and at days 2 and 3 after calving and at dry off.

\subsection{Milk yield and composition}

Individual milk yield (True-tester) and content of fat, protein and somatic cell counts (MilkoScan FT 120 infrared analyzer, Foss Electric A/S, 3400 Hillerød, Denmark) were measured fourth-nightly.

Milk quality from comparable cows in early, mid and late lactation (around days 45, 150 and 285, respectively) in groups $\mathrm{N}$ and $\mathrm{L}$ was investigated in more detail during one winter period in 83 milk samples from six sampling dates. Milk fat, milk protein were measured by MilkoScan FT 120 infrared analyzer (Foss Electric A/S, 3400 Hillerød, Denmark), and casein, whey protein and non-protein-

Table 2

Mean grazing and sward heights, and mean size of rejected area around dung pats in paddocks grazed by groups $\mathrm{L}$ and $\mathrm{N}$

\begin{tabular}{lllllll}
\hline Group & $\begin{array}{l}\text { Grazing } \\
\text { height } \\
(\mathrm{cm})\end{array}$ & $\begin{array}{l}\text { Sward } \\
\text { height } \\
(\mathrm{cm})\end{array}$ & $\begin{array}{l}\text { Rejected } \\
\text { areas } \\
\left(\mathrm{m}^{2}\right)\end{array}$ & $\begin{array}{l}\text { Digesti- } \\
\text { bility } \\
(\% \text { of OM })\end{array}$ & $\begin{array}{l}\text { Crude } \\
\text { protein } \\
(\% \text { of DM })\end{array}$ & $\begin{array}{l}\text { Crude } \\
\text { fibre } \\
(\% \text { of DM })\end{array}$ \\
\hline L & 3.6 & 4.6 & 0.73 & 73.8 & 21.1 & 20.5 \\
N & 3.2 & 3.8 & 0.63 & 74.3 & 22.9 & $\mathrm{~ns}$ \\
LSD 0.05 & 0.3 & 0.5 & 0.09 & $\mathrm{~ns}$ & $\mathrm{~ns}$ \\
\hline
\end{tabular}

Measurements were taken seven times during two of the three grazing seasons. 
nitrogen (NPN) were analysed according to Hermansen et al. (1999). Level of free fatty acids in the milk (BDI degree) was determined by the BDI method (IDF, 1991).

\subsection{Calculations and statistics}

A cow year was defined as 365 feeding days in the experimental herd. The winter feed efficiency was calculated as the ratio between the expected energy requirement for the recorded production and the actual energy intake. Grass intake during grazing was calculated from recorded milk yield and supplement intake, standard requirement for maintenance, growth and foetus (1904 SFU/14 851 MJ NE per cow year) corrected for the group-specific winter feeding efficiency.

Somatic cell counts were calculated as the geometric average of the individual cell count based on the logarithmized data. Energy corrected milk yield (ECM) was calculated according to Sjaunja et al. (1990).

Digestible energy (DE), net energy (NE) and Scandinavian Feed Units (SFU) were calculated according to Weisbjerg and Hvelplund (1993). Amino acids absorbed in the small intestine (AAT) and protein balance in the rumen (PBV) were calculated according to Madsen et al. (1995).

Data were analyzed using PC-SAS version 8 (SAS Institute Inc., 1999). For analyzing Model (1) and (2) the General Linear Models Procedure (Proc GLM) was used. For analyzing Model (3) the Generalized Linear Models Procedure (Proc Genmod) was used.

The following full Model (1) was used analyzing milk yield, ECM, milk protein and milk fat per day in milk yield, and yield of ECM in the first 24 weeks (168 days) after calving. However, only parameters which reduced the variation significantly were included in the final reduced model.

$$
\begin{aligned}
Y_{i j k n}= & \mu+\alpha_{i}+\beta_{j}+\delta_{k}+\alpha_{i} \beta_{j}+\alpha_{i} \delta_{k}+\beta_{j} \delta_{k} \\
& +\alpha_{i} \beta_{j} \delta_{k}+\varepsilon_{i j k n}
\end{aligned}
$$

where $Y_{i j k n}=$ response parameter for cow $n$ in group $i$ and parity $j$ and of breed $k ; \mu=$ overall mean; $\alpha_{i}=$ fixed effect of group $i, i=(\mathrm{L}, \mathrm{L}+, \mathrm{N}) ; \beta_{j}=$ fixed effect of parity $j, j=$ (first, later); $\delta_{k}=$ fixed effect of breed $k, k=(\mathrm{SDM}, \mathrm{RDM}, \mathrm{CROSS})$; and $\varepsilon_{i j k n}=$ residual error, $N\left(0, \sigma_{\varepsilon}^{2}\right)$ and independent.

The following reduced Model (2) was used analyzing sward structure and herbage quality:

$$
Y_{i j k}=\mu+\alpha_{i}+\beta_{j}+\alpha_{i} \beta_{j}+\gamma_{k}+\varepsilon_{i j k}
$$

where $Y_{i j k}=$ the response parameter for group $i$ and year $j$ and replicate $k ; \mu=$ overall mean; $\alpha_{i}=$ fixed effect of group $i, i=(\mathrm{L}, \mathrm{N}) ; \beta_{j}=$ fixed effect of year $j, j=(1,2) ; \gamma_{k}=$ fixed effect of replicates $k, k=(1,2)$; and $\varepsilon_{i j k}=$ residual error, $N\left(0, \sigma_{\varepsilon}^{2}\right)$ and independent.

The following reduced Model (3) was used analyzing the frequency of treatments of clinical disease and frequency of cows being treated for clinical disease, under the assumption that data was binomial distributed $b\left(n_{i}, p_{i}\right)$ and using the logit link function:

(3) $\operatorname{logit}\left(p_{i}\right)=\mu+\alpha_{i}$

where $p_{i}=$ the frequency in group $i ; \mu=$ overall mean; and $\alpha_{i}=$ fixed effect of group $i, i=(\mathrm{L}, \mathrm{L}+$, $\mathrm{N})$.

\section{Results}

\subsection{Feed intake}

The average net energy (NE) and dry matter (DM) intake from four main types of feeds are given in Table 3. The differences in concentrate intake were in accordance with the experimental plan, and the apparent substitution rate on a dry matter basis (concentrate to silage plus grass) was 0.43 between groups $\mathrm{L}$ and $\mathrm{L}+$, and 0.30 between groups $\mathrm{L}+$ and $\mathrm{N}$. However, the intake of roughage (silage and grazed clover-grass) did not reach the planned level due to a relatively low silage quality (Table 1), and a non-optimal herbage allowance in the chosen grazing system, with grazing height of $3.2-3.6 \mathrm{~cm}$ in the two groups (Table 2) (Peyraud and González-Rodrigez, 2000). The herbage allowance was higher in the paddocks grazed by group L than by group $\mathrm{N}$, as the sward height and the rejected area were higher in the paddocks grazed by group L. 
Table 3

Feed intake per cow year in the three groups in MJ NE and kg DM

\begin{tabular}{|c|c|c|c|c|c|c|}
\hline \multirow{3}{*}{$\begin{array}{l}\text { Feed intake } \\
\text { per cow year }\end{array}$} & \multicolumn{6}{|l|}{ Group } \\
\hline & \multicolumn{2}{|l|}{$\mathrm{L}$} & \multicolumn{2}{|l|}{$\mathrm{N}$} & \multicolumn{2}{|l|}{$\mathrm{L}+$} \\
\hline & MJ NE & $\mathrm{kg} \mathrm{DM}$ & MJ NE & $\mathrm{kg} \mathrm{DM}$ & MJ NE & $\mathrm{kg} \mathrm{DM}$ \\
\hline Total & 31536 & 4770 & 44895 & 6226 & 36302 & 5266 \\
\hline Silage & 17705 & 2933 & 14494 & 2407 & 16198 & 2683 \\
\hline Grazing & 11298 & 1504 & 9287 & 1236 & 10265 & 1366 \\
\hline Fodder beets & 1539 & 207 & 1681 & 224 & 1428 & 193 \\
\hline Concentrates & 994 & 126 & 19433 & 2359 & 8411 & 1024 \\
\hline
\end{tabular}

MJ NE, mega joule net energy; DM, dry matter.

\subsection{Milk production and efficiency}

The milk yield in group $\mathrm{N}$ was $6723 \mathrm{~kg}$ ECM per cow year (Table 4). The efficiency of milk production is expressed as the feed efficiency (energy requirement for maintenance and obtained production over actual energy intake) and as produced ECM over energy and DM intake. In group $\mathrm{L}+$ the lower energy intake by $19 \%$ caused only a $7 \%$ reduction in ECM yield (minus $493 \mathrm{~kg} \mathrm{ECM}$ ), and thereby an increase in efficiency. In group L the further $13 \%$ reduction in feed intake caused $18 \%$ decrease in ECM yield and, a slight increase in feed efficiency, but a decrease in milk production per MJ NE intake and per $\mathrm{kg} \mathrm{DM}$ intake.

The somatic cell counts in milk were not significantly effected by group. The geometric mean for the herd over the full period was 145000 cells per $\mathrm{ml}$ of milk, and 91000 cells per ml milk in the first 24 weeks of lactation.

The milk yield and milk composition per day in milk is shown in Table 5. The statistical analysis showed significant systematic effects of group, breed and parity for all response parameters except for fat percentage, which was only significantly affected by breed (data not shown). The milk yield per day in milk was reduced by 8 and $19 \%$ in groups $\mathrm{L}+$ and $\mathrm{L}$, respectively, as compared with group $\mathrm{N}$. The yield of milk protein per day in milk was reduced by 9 and $22 \%$ in groups $\mathrm{L}+$ and $\mathrm{L}$, respectively, as compared with group N. This caused a significantly lower milk protein content in group $\mathrm{L}$ as compared with groups $\mathrm{N}$ and $\mathrm{L}+$. The yield of milk fat (g per day) was reduced by $19 \%$ in group $\mathrm{L}$, as compared with group $\mathrm{N}$, but this caused no significant differences in the milk fat content as compared to group N. However,

Table 4

Milk yield and composition per cow year, and milk production efficiency in winter periods expressed as the feed efficiency (energy requirement over actual energy intake) and as energy and dry matter intake over produced ECM

\begin{tabular}{llll}
\hline & Group & & $\mathrm{N}$ \\
\cline { 2 - 4 } & $\mathrm{L}$ & & $\mathrm{L}+$ \\
\hline Per cow year & & 5723 & 6230 \\
ECM (kg) & 5090 & 6646 & 6027 \\
Milk (kg) & 5030 & $225 / 3.39$ & $203 / 3.36$ \\
Milk protein $(\mathrm{kg} / \%)$ & $165 / 3.28$ & $273 / 4.11$ & $259 / 4.31$ \\
Milk fat (kg/\%) & $210 / 4.18$ & & 94 \\
Winter & & & 1.17 \\
Feed efficiency $(\%)$ & 98 & 1.04 & 1.31 \\
kg ECM per 7.89 MJ NE (1 SFU) & 1.21 & & 1.08 \\
kg ECM per kg DM & 0.97 & & \\
\hline
\end{tabular}


Table 5

Daily production of milk, ECM, milk fat and milk protein per day in lactation. Least square means and standard errors

\begin{tabular}{|c|c|c|c|c|c|}
\hline \multirow{2}{*}{$\begin{array}{l}\text { Yield per day } \\
\text { in milk }\end{array}$} & \multirow[b]{2}{*}{ All } & \multicolumn{3}{|l|}{ Group } & \multirow{2}{*}{$\begin{array}{l}P \text { value } \\
\text { group }\end{array}$} \\
\hline & & $\mathrm{L}$ & $\mathrm{N}$ & $\mathrm{L}+$ & \\
\hline$\overline{\text { Milk (kg) }}$ & $19.4 \pm 0.3$ & $17.0 \pm 0.7^{\mathrm{a}}$ & $21.1 \pm 0.6^{\mathrm{b}}$ & $19.4 \pm 0.4^{\mathrm{c}}$ & 0.0001 \\
\hline ECM (kg) & $19.9 \pm 0.3$ & $17.0 \pm 0.6^{\mathrm{a}}$ & $21.2 \pm 0.6^{\mathrm{b}}$ & $20.0 \pm 0.4^{\mathrm{c}}$ & 0.0001 \\
\hline Fat $(g)$ & $823 \pm 10$ & $694 \pm 25^{a}$ & $852 \pm 23^{\mathrm{b}}$ & $828 \pm 16^{\mathrm{b}}$ & 0.0001 \\
\hline Fat $(\%)$ & $4.22 \pm 0.05$ & $4.08 \pm 0.11^{\mathrm{a}}$ & $4.04 \pm 0.10^{\mathrm{a}}$ & $4.27 \pm 0.07^{\mathrm{a}}$ & 0.17 \\
\hline Protein $(\mathrm{g})$ & $649 \pm 8$ & $556 \pm 19^{\mathrm{a}}$ & $715 \pm 18^{\mathrm{b}}$ & $651 \pm 13^{\mathrm{c}}$ & 0.0001 \\
\hline Protein $(\%)$ & $3.35 \pm 0.02$ & $3.27^{\mathrm{a}} \pm 0.04^{\mathrm{a}}$ & $3.39 \pm 0.04^{\mathrm{b}}$ & $3.36 \pm 0.03^{\mathrm{b}}$ & 0.016 \\
\hline
\end{tabular}

Different letters in superscript indicates significant differences between the groups (same line).

the fat content tended to be higher in group $\mathrm{L}+$ $(P=0.07)$, as compared to groups $\mathrm{N}$ and $\mathrm{L}$. Due to the higher fat content in milk from group $\mathrm{L}+$ the ECM yield was lowered by only $6 \%$ as compared to group N. On the contrary, the $19 \%$ reduction in milk yield observed in group L as compared with group $\mathrm{N}$, was increased to $20 \%$ when measured as ECM, due to a lower protein content in milk from group L.

There were no significant effects of season (plus/ minus grazing) or interactions between group and season on milk production parameters per day in lactation. However, the tendency was a higher production of milk and milk protein and a lower production of milk fat during the grazing season in all groups.

The effects of group and parity (first or later lactations) on production of ECM in the first 24 weeks of lactation are shown in Table 6 . The overall responses did not differ from the responses seen over the lactation as a whole (Table 5). However, the table shows that the older cows responded signifi- cantly to the reduced supplementation in group $\mathrm{L}+$, whereas the small response in first parity cows was non-significant. There were no group-parity interaction $(P=0.52$ for model effect).

Milk quality from comparable cows in early, mid and late lactation (around days 45, 150 and 285, respectively) in groups $\mathrm{N}$ and $\mathrm{L}$ was investigated in more detail during one winter period (Table 7). The

Table 7

Milk quality parameters from groups $\mathrm{L}$ and $\mathrm{N}$ : least-square means and standard errors

\begin{tabular}{lccl}
\hline Parameter & Group N & Group L & $\begin{array}{l}P \text { value } \\
\text { for N=L }\end{array}$ \\
\hline BDI degree & $0.38 \pm 0.06$ & $0.74 \pm 0.05$ & 0.0001 \\
NPN $(\%)$ & $0.027 \pm 0.001$ & $0.027 \pm 0.001$ & 0.58 \\
Whey N $(\%)$ & $0.113 \pm 0.002$ & $0.106 \pm 0.002$ & 0.02 \\
Fat $(\%)$ & $4.47 \pm 0.10$ & $4.29 \pm 0.09$ & 0.18 \\
Protein $(\%)$ & $3.61 \pm 0.04$ & $3.32 \pm 0.04$ & 0.0001 \\
\hline
\end{tabular}

BDI degree, level of free fatty acids (BDI method).

Table 6

Yield of ECM $(\mathrm{kg})$ in the first 24 weeks after calving for cows, which calved and carried through minimum 168 days of lactation within the experimental period: least-square means and standard errors

\begin{tabular}{|c|c|c|c|c|c|c|}
\hline & \multirow[b]{2}{*}{ All } & \multicolumn{3}{|l|}{ Group } & \multicolumn{2}{|l|}{$P$ value } \\
\hline & & $\mathrm{L}$ & $\mathrm{N}$ & $\mathrm{L}+$ & Group & Parity \\
\hline$\overline{A l l}$ & $20.8 \pm 0.4(98)^{1}$ & $17.6 \pm 0.8^{\mathrm{a}}(24)$ & $22.4 \pm 0.8^{\mathrm{b}}(25)$ & $21.0 \pm 0.6^{\mathrm{b}}(49)$ & 0.0004 & 0.0001 \\
\hline 1. After first calving & $17.9 \pm 0.7(42)$ & $15.5 \pm 1.3^{\mathrm{a}}(10)$ & $19.2 \pm 1.2^{\mathrm{b}}(12)$ & $18.9 \pm 0.9^{\mathrm{b}}(20)$ & & \\
\hline 2. After later calvings & $22.8 \pm 0.6(56)$ & $19.7 \pm 1.1^{\mathrm{a}}(14)$ & $25.5 \pm 1.1^{\mathrm{b}}(13)$ & $23.1 \pm 0.8^{\mathrm{c}}(29)$ & & \\
\hline$P$ value for $1=2$ & 0.0001 & 0.02 & 0.0002 & 0.0007 & & \\
\hline
\end{tabular}

Different letters in superscript indicate significant differences between the groups (same line).

${ }^{1}$ Number of observations (cows) in brackets. 
results confirm the overall observation (Table 5) that the protein content in milk from group $\mathrm{L}$ was significantly decreased, as compared to group $\mathrm{N}$. There was a parallel decrease in whey protein and casein content. Further, there was an increased level of free fatty acids (BDI degree) in milk from group $\mathrm{L}$, as compared with group $\mathrm{N}$.

\subsection{Reproduction}

Table 8 shows results on days to first insemination, calving interval, length of lactation and length of the dry period. There was a general tendency to an increasing number of days to first insemination with decreasing feeding level, and the difference was significant between cows in groups $\mathrm{N}$ and $\mathrm{L}$. The average number of inseminations per gestation was 1.7 , and there was no effect of group or parity. In group L the calving interval and length of the lactation period was significantly prolonged between first and second calving, as compared to later calvings and to group N. There was a general tendency of increasing calving interval and length of lactation with decreasing feeding level. There were no significant differences in length of the dry period between groups. There was no effect of group on the weight of the newborn calf, or on the proportion of live-born calves, which was $90.5 \%$ on average.

\subsection{Body weight}

The body weights of cows at calving, at 8 and 24 weeks after calving, and at dry off are shown in Fig. 1 for the first and second lactation. Weight at first calving was equal between groups, but at 24 weeks after parturition there was a significant effect of treatment. Group N was heavier than groups L and $\mathrm{L}+$. However, the difference disappeared at dry off before second calving, partly due to a later dry off in groups $\mathrm{L}$ and $\mathrm{L}+$. The same was observed during the second lactation.

\subsection{Health}

The frequency of clinical treatments per cow year is shown in Table 9 by main classes. The total number of treatments per cow year were significantly lower in group $\mathrm{L}(0.52)$, as compared to groups $\mathrm{N}$ (0.78) and $\mathrm{L}+(0.81)$. Group L differed by significantly lower treatment frequency for limb, metabolic and other diseases, whereas there was no

Table 8

Days to first insemination, calving interval, length of lactation and dry period. Least-square means and standard errors

\begin{tabular}{|c|c|c|c|c|c|c|}
\hline & \multirow[b]{2}{*}{ All } & \multicolumn{3}{|l|}{ Group } & \multicolumn{2}{|c|}{$P$ value } \\
\hline & & $\mathrm{L}$ & $\mathrm{N}$ & $\mathrm{L}+$ & Group & Parity \\
\hline Days to first insemination & & & & & 0.007 & 0.76 \\
\hline 1. After first calving & $80 \pm 5$ & $95 \pm 10^{\mathrm{a}}$ & $68 \pm 9^{b}$ & $78 \pm 7^{\mathrm{ab}}$ & & \\
\hline 2. After later calvings & $77 \pm 5$ & $89 \pm 10^{\mathrm{a}}$ & $60 \pm 8^{b}$ & $81 \pm 6^{\mathrm{a}}$ & & \\
\hline Calving interval (days) & & & & & 0.14 & 0.012 \\
\hline 1. First to second calving & $391 \pm 8$ & $415 \pm 14^{\mathrm{a}}$ & $370 \pm 14^{\mathrm{b}}$ & $389 \pm 11^{\mathrm{ab}}$ & & \\
\hline 2. Later calvings & $364 \pm 7$ & $364 \pm 14^{\mathrm{a}}$ & $356 \pm 13^{\mathrm{a}}$ & $371 \pm 9^{\mathrm{a}}$ & & \\
\hline $\mathrm{P}$ value for $1=2$ & 0.008 & 0.013 & 0.44 & 0.20 & & \\
\hline Dry period (days) & & & & & 0.160 & 0.250 \\
\hline 1. First to second calving & $36 \pm 3$ & $36 \pm 5$ & $30 \pm 5$ & $43 \pm 4$ & & \\
\hline 2. Later calvings & $41 \pm 3$ & $39 \pm 5$ & $42 \pm 5$ & $45 \pm 3$ & & \\
\hline Days in lactation & & & & & 0.234 & 0.109 \\
\hline 1. First lactation & $345 \pm 7$ & $362 \pm 13$ & $329 \pm 13$ & $343 \pm 9$ & & \\
\hline 2. Later lactations & $325 \pm 10$ & $327 \pm 21$ & $322 \pm 17$ & $326 \pm 12$ & & \\
\hline
\end{tabular}

Different letters in superscript indicate significant differences between the groups. Calculation of days in lactation was based only on full lactations which was terminated due to dry off before expected calving. 


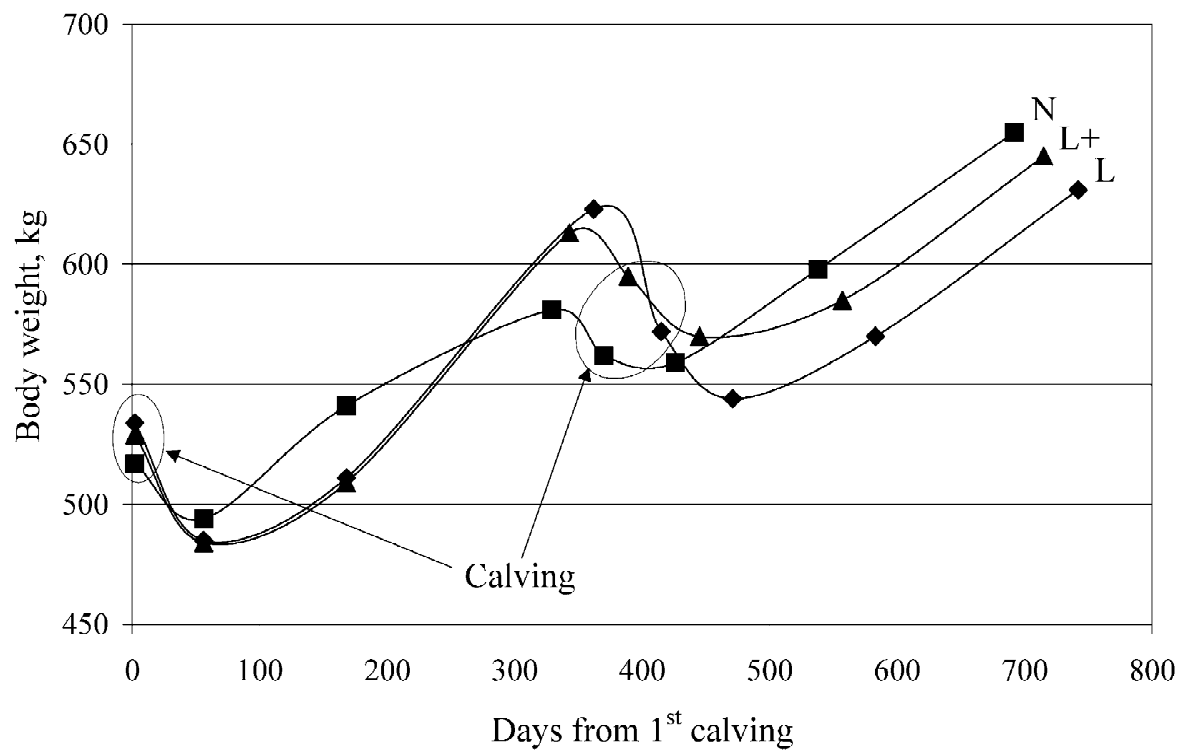

Fig. 1. Average body weights of cows during first and second lactation by group. Points given represent body weights at calving, at 8 and 24 weeks post calving and at dry off for first and second lactation.

Table 9

Frequency of clinical diseases per cow year. Treatment and re-treatment on the same animal within 10 days were calculated as one case

\begin{tabular}{llllll}
\hline & & \multicolumn{2}{l}{ Group } & $\begin{array}{l}P \text { value } \\
\text { group }\end{array}$ \\
\cline { 3 - 5 } Class of disease & All & $\mathrm{L}$ & $\mathrm{N}$ & $\mathrm{L}+$ & \\
\hline Mammary gland & 0.16 & 0.16 & 0.17 & 0.16 & 0.98 \\
Reproduction & 0.25 & 0.27 & 0.30 & 0.21 & 0.44 \\
Limb & 0.19 & $0.07^{\mathrm{a}}$ & $0.17^{\mathrm{ab}}$ & $0.25^{\mathrm{b}}$ & 0.022 \\
Metabolic & 0.07 & $0.02^{\mathrm{a}}$ & $0.02^{\mathrm{a}}$ & $0.12^{\mathrm{b}}$ & 0.027 \\
Other & 0.06 & $0.00^{\mathrm{a}}$ & $0.11^{\mathrm{b}}$ & $0.07^{\mathrm{b}}$ & 0.029 \\
Total & 0.73 & $0.52^{\mathrm{a}}$ & $0.78^{\mathrm{b}}$ & $0.81^{\mathrm{b}}$ & 0.0017 \\
\hline
\end{tabular}

Different letters in superscript indicate significant differences between the groups.

differences with respect to treatments related to the mammary gland or reproduction.

\section{Discussion}

In general, the quality of silages obtained was lower than that planned and the grazing system used did not support maximum herbage intake because of low herbage mass (Peyraud and González-Rodrigez, 2000). Therefore, this experiment did not show the full potential of systems with reduced or omitted concentrate supplementation for high genetic merit dairy cows. The experiment has indicated that systems with low energy intake do not necessarily cause increased health problems, neither when based on a relatively low silage quality and non-optimal herbage allowance during grazing. But there were clear consequences of reduced feeding level for the reproductive performance, which should be taken into account when planning such systems.

\subsection{Feed intake}

The overall apparent substitution rates on a dry matter basis between concentrates and roughage (silage and clover-grass) was 0.43 between groups $\mathrm{L}$ and $\mathrm{L}+$, and 0.30 between groups $\mathrm{L}+$ and $\mathrm{N}$. The substitution rates were calculated as the decrease in roughage DM intake per $\mathrm{kg}$ increase in concentrate DM intake. Thomas (1980) reported in a literature review an average substitution rate of 0.50 when feeding silage, and Peyraud and González-Rodrigez (2000), in another review, a rate of 0.60 in grazing systems. Dulphy (1980) found that the substitution rate increased with the quality of roughage and with an increasing level of concentrates. In the present 
study, the silages used were generally of low quality, and the level of concentrate feeding was relatively low as compared to conventional production systems. The levels of substitution rates found are therefore within the expected range.

\subsection{Milk production}

The milk production obtained with reduced concentrate levels in groups $\mathrm{L}$ and $\mathrm{L}+$ was in accordance with the levels that could be expected from well established knowledge on short-term responses to energy and nutrient supply in dairy cows (Spörndly, 1989; Kristensen and Skovborg, 1990; Kristensen, 1997). Further it was comparable to results from Krutzinna et al. (1996), who analysed 268 organic herds in Germany and found an average yield of $4941 \mathrm{~kg}$ per lactation with $580 \mathrm{~kg}$ concentrate supplementation. Olesen et al. (1999) found similar levels of milk production in Norwegian organic herds feeding low levels of concentrates. The production level in group $\mathrm{N}$ was $400 \mathrm{~kg}$ ECM lower than in commercial Danish organic herds although the amount of concentrate was higher, $43 \%$ in group $\mathrm{N}$, as compared to $34 \%$ of total energy intake in commercial herds (Morgensen et al., 1999).

The milk production capacity of the experimental herd could have been negatively influenced by the relatively short dry period length obtained, as it was only 36 days on average against 50 days for optimal production (Sørensen and Enevoldsen, 1991). Therefore, the obtained production response and marginal efficiency of the increased concentrate supplementation in group $\mathrm{N}$ were relatively low, and lower than expected (Kristensen and Aaes, 1989). However, first parity cows gave only a small and nonsignificant response of $0.3 \mathrm{~kg} \mathrm{ECM}$, whereas the older cows responded significantly with $2.4 \mathrm{~kg}$ ECM to the increased level of supplementation in group $\mathrm{N}$ as compared with group $\mathrm{L}+$ (see Table 6). This is partly contradictory to the expected increase in feed intake capacity with body weight and parity (Kristensen, 1983, 1995), but in good agreement with the increasing milk production potential with parity and the following ability to respond to an increased supply of energy and nutrients (Østergaard et al., 1994).

On average, milk production was only slightly higher in the grazing season than in the winter period although the energy content of the fresh clover-grass was considerable higher than of silage. The higher quality in the summer period could give the possibility for a higher intake by group L. However, this seemed not to be the case, as there was no significant interaction between group and season of production. Further, the L group did not seem to make full use of the allocated herbage, as both sward height and rejected areas were higher for this group (Table 2).

The decrease in milk protein content from 3.39 in group $\mathrm{N}$ to 3.27 in group $\mathrm{L}$ (Table 5), should be explained by the lower energy intake, although others have found that protein content increases with increased proportion of pasture in the diet (Hermansen et al., 1994).

The milk quality parameters presented in Table 7 only represent a limited number of milk samples from one winter period, and should therefore be interpreted with caution. However, the decreased milk protein content was confirmed by the regular milk recordings (Table 5) and is therefore well documented. Milk protein content is known to be influenced by the supply of energy and amino acids (Spörndly, 1989; Kristensen, 1997) and so, the lowered protein content of milk from group L could be explained by both parameters (Table 1). There was, however, no indication that the proportion of caseins in milk protein was reduced in milk from group L. The increased degree of lipolysis and thereby content of free fatty acids in milk from group L, could potentially impair the flavour of the milk.

\subsection{Health}

A major concern when planning the experiment was how the reduced feeding level would affect health and reproduction due to increased mobilisation of body reserves and a more negative energy balance in early lactation (Kronfeld, 1982; Butler and Smith, 1989). Fraser and Leaver (1988), on the other hand, did not find any difference in reproduction performance at feeding levels comparable to $\mathrm{L}$ and $\mathrm{L}+$. In spite of a relatively low quality of forage which could be expected to put further pressure to this health complex, the disease incidences during the present experiment were generally at a low and acceptable level (Sundrum, 2001; Trinderup et al., 
2001), and did not indicate disease problems related to reduced feeding level as practised in this experiment.

The total frequency of clinical diseases was markedly lower in group $\mathrm{L}$ than in the two other groups. In a survey of 10 organic herds Weller and Bowling (2000) found a level of treatment frequency that was similar to the level in groups $\mathrm{N}$ and $\mathrm{L}+$. Based on this the treatment frequency in group L (0.52) can be characterized as low. A lower treatment frequency in herds with low production level was also found by Hardeng and Edge (2001).

\subsection{Reproduction}

Reproduction is likely to be negatively influenced as the energy balance in early lactation becomes more negative. This is often explained as competition for nutrients between milk production and reproduction. However, Pryce et al. (1999) did not find negative effects of decreasing concentrate levels from 2500 to $1000 \mathrm{~kg}$ per lactation in high genetic merit dairy cows. In the present study, there was a tendency to an increasing number of days to first insemination, increasing calving interval, and increasing length of lactation with decreasing feeding level, but significant differences were seen only for group $\mathrm{L}$ as compared to groups $\mathrm{L}+$ and $\mathrm{N}$. These effects were most pronounced for the first parity cows in group L.

\subsection{Efficiency}

The feed efficiency (ratio between recorded net energy intake and obtained energy in production response) decreased from $98 \%$ in group $\mathrm{L}$ to $84 \%$ in group $\mathrm{N}$. The high efficiency in $\mathrm{L}$ and $\mathrm{L}+$ is expected according to Kristensen and Aaes (1989), while an efficiency on $84 \%$ in group $\mathrm{N}$ is lower than expected. The average efficiency in commercial organic herds is $89 \%$ at a production level similar to group N (Kristensen and Mogensen, 1999).

The marginal efficiency of the concentrates supplied to group L + was high (80\%), when comparing to group L (Kristensen and Aaes, 1989; Østergaard et al., 1989). This illustrates the nutritional benefit of supplementing a small amount of concentrates. In this experiment the benefit of further supple- mentation was low, as the marginal feed efficiency from group $\mathrm{L}+$ to $\mathrm{N}$ was only $18 \%$. This could be a result of too high level of concentrates, confirmed by the slightly (non-significant) reduced milk fat content, but also a generally too high energy level as compared to the yield potential of the herd.

The feed conversion rate ( $\mathrm{kg}$ ECM per SFU) was highest in group $\mathrm{L}+$ (1.31) against 1.21 and 1.17 in groups $\mathrm{L}$ and $\mathrm{N}$, respectively. Kristensen and Mogensen (1999) reported a feed conversion of 1.32 kg ECM per SFU in commercial organic herds. The lower feed conversion in group L was a expected result due to the decreased milk yield and relatively increased proportion of energy being allocated to maintenance, while the lower feed conversion rate in group $\mathrm{N}$ was a result of the relatively high feed energy intake (excessive supplementation) as compared to the yield potential of the herd.

\section{Conclusion}

Omission of concentrate supplementation to high merit cows reduced feed energy intake by $30 \%$ and milk production by $24 \%$. Milk protein content was reduced and free fatty acid content was increased, feed conversion ratio was improved by $3 \%$, and the interval between first and second calving was significantly increased by 45 days, as compared with traditional feeding with $38 \%$ of DM from concentrates. Concentrate supplementation in reduced amount $(19 \%$ of DM) - but strategic in relation to the total nutrient demand - reduced milk production by only $7 \%$, primarily due to a significantly improved feed conversion ratio (12\%). In this experiment the benefit of further supplementation was low. There were no indications of health problems associated with the reduced feeding levels.

\section{Acknowledgements}

This work was supported by the Danish Directorate for Food, Fisheries and Agri Business through The Danish Research Centre for Organic Farming. Thanks are due to Senior Scientist Verner Friis Kristensen, Scientist Torkil Stensig, Agricultural technicians Erling Olesen, Maarten van Leeuwen, 
Lars Bilde Gildbjerg, and Manager Kjeld Mortensen and his staff for skilled assistance.

\section{References}

AOAC, 1990. Official Methods of Analysis, 15th Edition. Association of Official Analytical Chemists International, Washington, DC.

Berg, J., Ekern, A., 1993. Long-term effects of concentrate level in dairy cows. Acta Agric. Scand. Sect. A, Anim. Sci. 43, $35-43$.

Broster, W.H., Broster, V.J., Clements, A.J., 1993. Feed utilisation by the dairy cow over multiple lactation: a review. Livest. Prod. Sci. 34, 1-21.

Butler, W.R., Smith, R.D., 1989. Interrelationships between energy balance and postpartum reproductive function in dairy cattle. J. Dairy Sci. 72, 767-783.

Dulphy, J.P., 1980. The intake of conserved forages. In: Thomas, C. (Ed.), Forage conservation in the 80's: Proc. Conf. Eur. Grassl. Fed., Brighton, UK, pp. 27-30.

EU, 1999. Council Directive no. 1804/1999 of 19 July 1999. Off. J. Eur. Communities 222, 1-28.

Fraser, D., Leaver, J.D., 1988. A system study of high and low concentrate inputs for dairy cows: milk yield and composition, live weight, feed intake, fertility and health over 4 years. Res. Dev. Agric. 5, 93-101.

Hardeng, F., Edge, V.L., 2001. Mastitis, ketosis, and milk fever in 31 organic and 93 conventional Norwegian dairy herds. J. Dairy Sci. 84, 2673-2679.

Hermansen, J.E., Ostersen, S., Aaes, O., 1994. Effect of the levels of $\mathrm{N}$ fertilizer, grass and supplementary feeds on nitrogen composition and renneting properties of milk from cows at pasture. J. Dairy Res. 61, 179-189.

Hermansen, E., Ostersen, S., Justesen, N.C., Aaes, O., 1999. Effect of dietary protein supply on caseins, whey proteins, proteolysis, proteolysis, and renneting properties in milk from cows grazing clover or N fertilized grass. J. Dairy Res. 66, 193-205.

International Dairy Federation, 1991. Determination of free fatty acids in milk. Int. Dairy Fed. 291, 1-51.

Jakobsen, K., Hermansen, J.E., 2001. Organic farming-a challenge to nutritionists. J. Anim. Feed Sci. 10 (1), 29-42.

Kristensen, V.F., 1983. Styring af foderoptagelsen ved hjælp af foderrationens sammensætning og valg af fodringsprincip (Management of feed intake by composition of the feed ration and choice of feeding principle). In: Østergaard, V., NeimannSørensen, A. (Eds.), Optimum Feeding of the Dairy Cow. Feed Composition, Feed Intake, Metabolism and Production. Report no. 551 from the National Institute of Animal Science, Denmark, pp. 7.1-7.35. (In Danish).

Kristensen, V.F., 1995. Forudsigelse af foderoptagelsen hos malkekøer (Prediction of feed intake in dairy cows). In: Malkekøernes Ernæring (The Nutrition of Dairy Cows). Internal Report no. 61, Danish Institute of Agricultural Sciences. (In Danish).
Kristensen, V.F., 1997. Optimal proteinforsyning (Optimum protein supply). In: Malkekøernes Ernæring (The Nutrition of Dairy Cows). Internal Report no. 88, Danish Institute of Agricultural Sciences, Chapter 4. (In Danish).

Kristensen, T., Mogensen, L., 1999. Organic dairy cattle production systems-feeding and feed efficiency. In: Ecological Animal Husbandry in the Nordic Countries. Proceedings NJFseminar No. 303, Horsens, Denmark, 16-17 September. DARCOF Report No 2, pp. 173-178.

Kristensen, V.F., Aaes, O., 1989. The effect of feeding level on feed efficiency. In: Østergaard, V., Neimann-Sørensen, A. (Eds.), Basis for Choice of Breeding Goal and Matching Production System within Dairy Herds. Report no. 660, National Institute of Animal Science, Denmark, Chapter 2. (In Danish with abstracts and subtitles in English).

Kristensen, V.F., Skovborg, E.B., 1990. Betydningen af tidspunkt for 1. slæt i græs for græsudbytte og-kvalitet og for ensilageoptagelse og produktion hos malkekøer. Report no. 15 from The National Institutes of Plant Crop Science and Animal Science, Denmark. (In Danish).

Kronfeld, D.S., 1982. Major metabolic determinants of milk volume, mammary efficiency, and spontaneous ketosis in dairy cows. J. Dairy Sci. 65, 2204-2212.

Krutzinna, C., Boehncke, E., Herrmann, H.-J., 1996. Organic Milk Production in Germany. Biol. Agric. Hort. 13, 351-358.

Madsen, J., Hvelplund, T., Weisbjerg, M., Bertilsson, J., Olsson, I., Spörndly, R., Harstad, O.M., Volden, H., Tuori, M., Varvikko, T., Huhtanen, P., Olafsson, B.L., 1995. The AAT/PBV protein evaluation system for ruminants. A revision. Norwegian J. Agric. Sci. (Suppl.) 19, 1-37.

Mogensen, L., Kristensen, T., Kristensen, I.S., 1999. Økologisk Kvægproduktion. Teknisk- $\varnothing$ konomiske gårdresultater 1997-98. Typetal for $\varnothing$ kologisk mælkeproduktion. DJF-rapport 10 . Husdyrbrug. 138 pp. (In Danish with English summary).

Nielsen, L.A.H., 2001. In: Produktionsmæssige resultater i $\emptyset$ kologiske malkekvægsbesætninger. Årsrapport, Landsudvalget for kvæg, Århus, Denmark, pp. 18-19, (In Danish).

Olesen, I., Lindhardt, E., Ebbesvik, M., 1999. Effects of calving season and sire's breeding value in a dairy herd during conversion to ecological milk production. Livest. Prod. Sci. 61 (2-3), 201-211.

Padel, S. (2000), Strategies of organic milk production. 3rd NAHWOA Workshop, 21-24 October 2000.

Peyraud, J.L., González-Rodrigez, A., 2000. Relations between grass production, supplementation and intake in grazing dairy cows. Grassland Sci. Eur. 5, 269-282.

Pryce, J.E., Nielsen, B.L., Veerkamp, R.F., Simm, G., 1999. Genotype and feeding system effects and interactions for health and fertility traits in dairy cattle. Livest. Prod. Sci. 57, 193 201.

Reksen, O., Tverdal, A., Ropstad, E., 1999. A comparative study of reproductive performance in organic and conventional dairy husbandry. J. Dairy Sci. 82, 2605-2610.

SAS Institute Inc., 1999. SAS Version 8, SAS OnlineDoc, SAS Institute Inc., Cary, USA.

Sjaunja, L.O., Baevre, L., Junkkarinen, L., Pedersen, J., Setälä, J., 1990. A Nordic Proposal for an Energy Corrected Milk (ECM) formula. 27th Session. ICRPMA. 2-6 July 1990, Paris. 
Spörndly, E., 1989. Effects of diet on milk composition and yield of dairy cows with special emphasis on milk protein content. Swedish J. Agric. Res. 19, 99-106.

Stoldt, W., 1952. Vorslag zur Vereinheitlichung der Fettbestimmung in Lebensmitteln. Fette Seifen 54, 206-207.

Strudsholm, F., Nielsen E.S., Madsen, J., Foldager, J., Hermansen, J.E., Kristensen, V.F., Aaes, O., Hvelplund, T., 1992. Danske fodernormer til kvæg (Danish Nutrient Requirements for Dairy Cattle). Report no. 18 from The National Committee on Danish Cattle Husbandry, Denmark.

Sundrum, A., 2001. Organic livestock farming. A critical review. Livest. Prod. Sci. 67, 207-215.

Sørensen, J.T., Enevoldsen, C., 1991. Effect of dry period length on milk production in subsequent lactation. J. Dairy Sci. 74, $1277-1283$.

Tecator AB, 1978. Determination of crude fibre in some feed and food samples by using the fibertec system and Weende method. Tecator AB, Box 70, S-26301 Hoganæs, Sweden. Application Note 01 .

Thomas, C., 1980. Conserved forages. In: Feeding Strategies for Dairy Cows. ARC Seminar, Harrogate, UK, 1979, pp. 8.18.14 .

Tilley, J.M.A., Terry, A., 1963. A two stage technique for the digestion of forage crops. J. Br. Grassld. Soc. 18, 104-111.

Trinderup, M., Kjeldsen, A.M., Andersen, O., 2001. Forskellige behandlingsfrekvenser af malkekøer i forskellige staldsystemer. LK-meddelelse nr. 905, Landskontoret for Kvæg (Danish Cattle), Denmark. (In Danish).
Weisbjerg, M.R., Hvelplund, T., 1992. Beregning af nettoenergiindhold $\left(\mathrm{FE}_{\mathrm{k}}\right)$ i kraftfoderblandinger til kvæg ud fra kemisk sammensætning samt fordøjeligheden af organisk stof. Meddelelse nr. 813. Statens Husdyrbrugsfors $\varnothing \mathrm{g} /$ National Institute of Animal Science, Denmark. (In Danish).

Weisbjerg, M.R., Hvelplund, T., 1993. Estimation of net energy content (FU) in feeds for cattle. Report No. 3/1993 from the National Institute of Animal Science, Denmark.

Weller, R.F., Bowling, P.J., 2000. Health status of dairy herds in organic farming. Vet. Rec. 146 (3), 80-81.

Østergaard, V., 1979. Strategies for concentrate feeding to attain optimum feeding level in high yielding dairy cows. Report no. 482 from the National Institute of Animal Science, Denmark.

Østergaard, V., Kristensen, L.G., Thysen, I., 1989. Feed efficiency at different genotype, production system and feeding level in Danish dairy farms during the years 1967 to 1986. In: Østergaard, V., Neimann-Sørensen, A. (Eds.), Basis for Choice of Breeding Goal and Matching Production System within Dairy Herds. Report no. 660, National Institute of Animal Science, Denmark, Chapter 6. (In Danish with abstracts and subtitles in English).

Østergaard, S., Sørensen, J.T., Kristensen, V.F., Kristensen, T., 1994. Modelling of the production of a dairy cow in a net energy system. Presentation and documentation of the PCmodel SIMCOW. Report no. 24 from the National Institute of Animal Science, Denmark. 